\title{
Sediment flow behaviour from small agricultural watersheds
}

\author{
P. Pathak*, S.P. Wani, Piara Singh, R. Sudi \\ International Crops Research Institute for the Semi-Arid Tropics, P.O. Patancheru 502324, AP, India
}

Accepted 2 February 2004

\begin{abstract}
Runoff, soil loss, sediment concentration, and particle size distribution of sediment eroded by runoff events were measured between 1976 and 2000 from 5 small agricultural watersheds on Vertisols at ICRISAT Center, Patancheru, India. The effects of storm size and land management system on total soil loss and size distribution of sediment during runoff are discussed. At the beginning of runoff events, the clay content of the eroded material was greater than that of the top soil but as the process of runoff continued, the clay content of the sediment tended to decrease. Generally smaller storms produced eroded material with higher clay content than did the bigger storms. Large differences in particle size distribution between the land management treatments were observed for small and medium runoff events, however, these differences were small during big runoff events. The particle size distributions of sediments eroded by big storms were comparable to the size distribution of cultivated top soil of the watersheds. The peak sediment concentration for most of the storms, generally preceded or occurred simultaneously with peak runoff rates. At about the peak runoff rate of most runoff events, the texture of the eroded soil was similar to the cultivated top soil of the watershed. Land management systems not only had significant effect on runoff and soil loss but also on the particle size distribution of eroded materials.
\end{abstract}

() 2004 Elsevier B.V. All rights reserved.

Keywords: Sediment flow; Agricultural watershed; Eroded sediments; Land and water management; Semi-arid tropics

\section{Introduction}

The impact of soil erosion on the productive potential of agricultural lands is well known. In recent years, however, there has been an increasing concern about the serious threat to downstream environmental quality due to eroded sediment movement by runoff from agri-

\footnotetext{
* Corresponding author. Tel.: +91-40-23296161x2337; fax: +91-40-23241239/23296182.

E-mail address: p.pathak@ cgiar.org (P. Pathak).
} 
cultural lands (Chichester and Richardson, 1992). Most of agricultural chemicals are also carried to streams and reservoirs through sediment transport. Chemical pollutants are more readily adsorbed by clay particles due to their greater surface area and cation exchange capacity. Thus, not only is the total quantity of sediment important with regards to pollution, but also the size distribution of the eroded material (Gilley et al., 1987; Sutherland, 1991). Knowledge about the transport and composition of sediments and chemicals associated with them is important in choosing management practices that will reduce potential pollution hazards. The impetus to erosion and chemical transport modeling work based upon fundamental erosion mechanics (Foster et al., 1980; Overton, 1992) has also created the need to better understand sediment properties and its flow behavior from agricultural areas (Onstad et al., 1979; Young, 1980; Alberts et al., 1983).

Most investigations conducted during the past 50 years have been concerned mainly with total soil loss (Mitchell et al., 1983). Only few studies on physical and chemical properties of eroded soil such as particle size distribution (Alberts et al., 1980; Meyer et al., 1980; Young, 1980; Mitchell et al., 1983) and transport phenomena of eroded materials (Young, 1980; Hamlett et al., 1987) have been reported. Pertinent field data on the rates and size distribution of sediments, particularly from small agricultural watersheds, particularly from semi-arid areas are lacking (Meyer et al., 1981; Pathak and Miranda, 1982; Niebling et al., 1983; Gilley et al., 1985; Hamlett et al., 1987). This paper describes the sediment flow behavior from five small agricultural watersheds under different land and water management systems on Vertisols. The variation in size distribution of sediment during runoff and effect of storm size and land management system on the total soil loss and size distribution of the sediment are discussed.

\section{Materials and methods}

\subsection{Description of research area}

Studies were conducted during 1976-2000 on small agricultural watersheds at the ICRISAT Center near Hyderabad, India. The five small watersheds on which studies were done are identified as the BW1, BW2, BW3B, BW7A and BW7B. On BW1, BW2, and BW3B watersheds the observations were collected during 1976-2000 while on BW7A and BW7B watersheds observations were collected only during 1995-2000. A description of the watersheds including area, and land management systems is given in Table 1 . The entire area of each watershed was cropped except for a very small portion under grassed waterways. Five land management systems viz. broadbed and furrow, broadbed and furrow with farmers field bunds, flat cultivation with field bunds, flat cultivation with graded bunds and broadbed and furrow with vegetative bunds were studied on watersheds. Each watershed was treated with one of the above mentioned land management systems.

Mean annual rainfall for the site is $890 \mathrm{~mm}$ (database: 1974-2002) with a CV of $25 \%$. About $80 \%$ of total rainfall is received from June to September each year. The rainy season starts in the standard week 23 (4-10 June) when the crops are sown. Rainfall exceeds potential evapotranspiration from week 29 (16-22 July) to week 40 (1-7 October) during which period significant amount of runoff and soil erosion occurs (Fig. 1). Analysis of the 
Table 1

Description of the five Vertisol watersheds at ICRISAT, Patancheru, India

\begin{tabular}{lll}
\hline Watershed number & Area (ha) & Land management systems \\
\hline BW1 & 3.4 & BBF $^{\mathrm{a}}$ at $0.6 \%$ slope \\
BW2 & 4.0 & BBF at $0.6 \%$ slope with farmers field bunds \\
BW3B & 2.6 & Flat cultivation with field bunds \\
BW7A & 1.3 & Flat cultivation with graded bunds \\
BW7B & 1.2 & BBF at $0.6 \%$ slope with vegetative bunds \\
\hline
\end{tabular}

${ }^{\mathrm{a}}$ Broadbed and furrow system.

daily rainfall has further shown that in almost all years at least two storms of more than $40 \mathrm{~mm}$ per day occur from June to October, and this number of events could be as high as 8 in some years (Fig. 2). However the frequency of larger storms ( $>60 \mathrm{~mm}$ per day) is about $70 \%$. These data indicate the frequency and potential of the rainfall environment to generate surface runoff and soil erosion for the experimental site.

Runoff behavior of the watersheds at the experimental site has been discussed in detail by Pathak et al. (1985), Pathak and Laryea (1990) and Pathak et al. (2002). The mean annual rainfall, runoff, peak runoff rate and soil loss from few watersheds are shown in Table 2 . The average seasonal runoff from these watersheds are in the range of $13-24 \%$ of the seasonal rainfall. During the high rainfall years $(\geq 900 \mathrm{~mm})$ the seasonal runoff could be as high as $40 \%$ and in low rainfall years $(\leq 650 \mathrm{~mm})$ as low as $1 \%$ of the seasonal rainfall. A close examination of soil loss and runoff trends within the season clearly shows that only a few major storms (>75 mm rainfall) determine the seasonal runoff and soil loss. In many years, these storms accounted for $75-91 \%$ of the seasonal runoff and $65-90 \%$ of the seasonal soil loss.

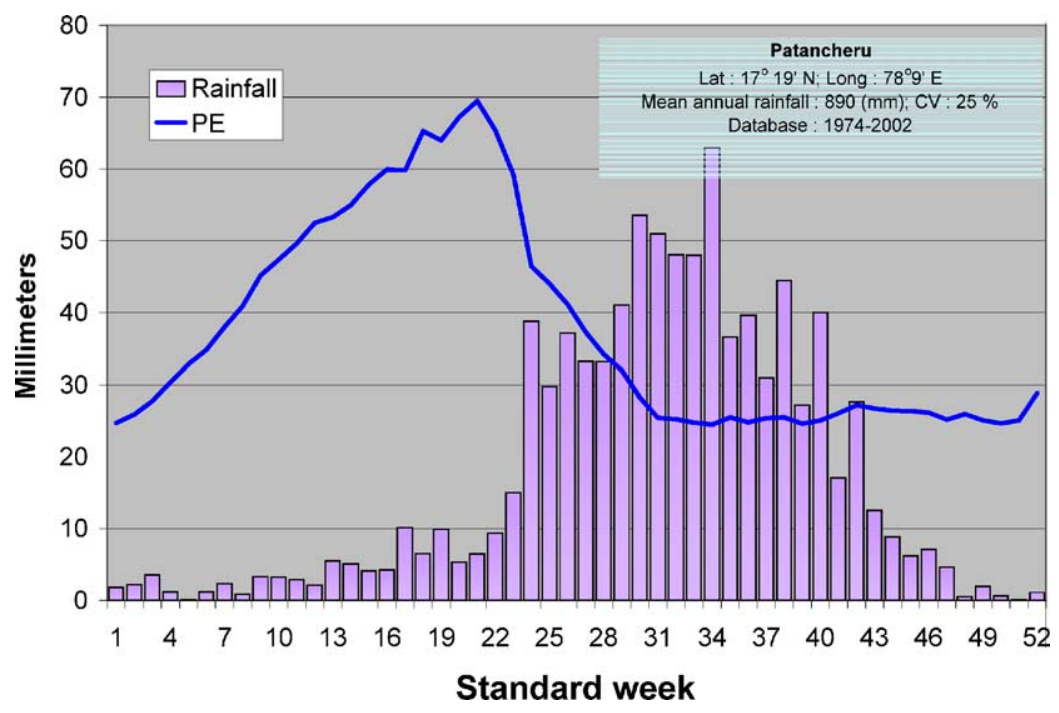

Fig. 1. Annual rainfall and potential evapotranspiration, ICRISAT, Patancheru, AP, India. 


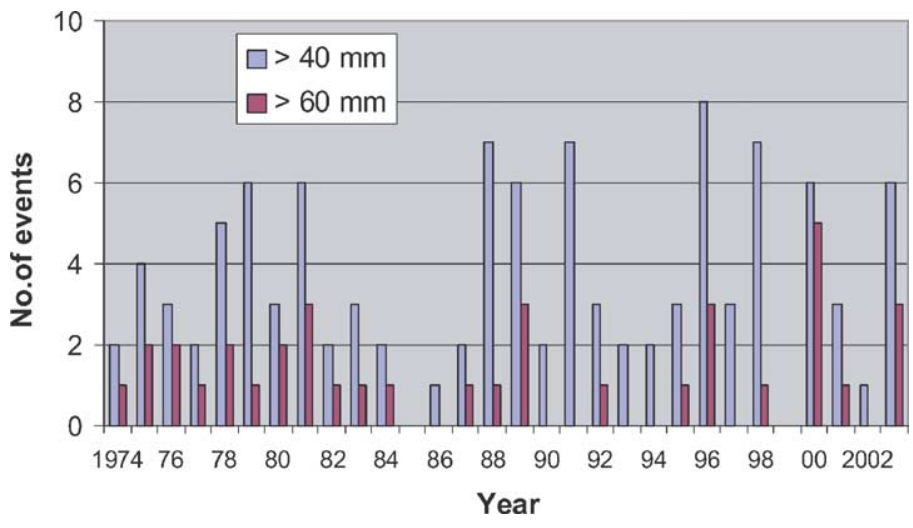

Fig. 2. Daily rainfall events $>40$ and $>60 \mathrm{~mm}$ per day at ICRISAT, Patancheru, AP, India.

The soils in the watersheds are Vertisols. The major physical and chemical properties of these soils have been reported by Pathak et al. (1985) and El-Swaify et al. (1985). These Vertisols belong to the very fine, clayey, montmorillonitic, calcareous hyperthermic family of Typic Pellustert. The soils are self-mulching and exhibit cracking upon drying. Because of the dominance of 2:1 type clay (smectite) and the relatively high clay content $(>45 \%)$, the soils are usually imperfectly drained and have a low to very low saturated hydraulic conductivity $\left(<1 \mathrm{~mm} \mathrm{~h}^{-1}\right)$.

\subsection{Measurements and analysis}

Rainfall amount and intensity were measured using three recording and five non-recording raingauges. Surface runoff from all watersheds was measured continuously using flumes and stage-level recorders. Both the Automatic runoff samplers (Pathak, 1991) and solar powered pumping type runoff samplers (Pathak, 1999) were used to collect runoff samples from each storm (Fig. 3). These automatic runoff samplers, collected and stored the runoff samples in separate containers at regular time intervals throughout the runoff period. These samples were analyzed for sediment concentration and particle size distribution of eroded soil material. Since each runoff samples and its sediment concentration represents a particular time and segment of runoff hydrograph. For every runoff event the sediment

Table 2

Mean annual rainfall, runoff, peak runoff rate and soil loss from Vertisol watersheds, ICRISAT, Patancheru, India (1974-2000)

\begin{tabular}{lllll}
\hline Name of watershed & Rainfall $(\mathrm{mm})$ & Runoff $(\mathrm{mm})$ & $\begin{array}{l}\text { Peak runoff rate } \\
\left(\mathrm{m}^{3} \mathrm{~h}^{-1} \mathrm{ha}^{-1}\right)\end{array}$ & Soil loss (tha $\left.{ }^{-1}\right)$ \\
\hline BW1 & 777 & 104 & 396 & 1.51 \\
BW7A $^{\mathrm{a}}$ & 797 & 223 & 605 & 4.24 \\
BW7B $^{\mathrm{a}}$ & 797 & 177 & 486 & 2.44 \\
\hline
\end{tabular}

\footnotetext{
${ }^{a}$ Monitored only during 1995-2000.
} 


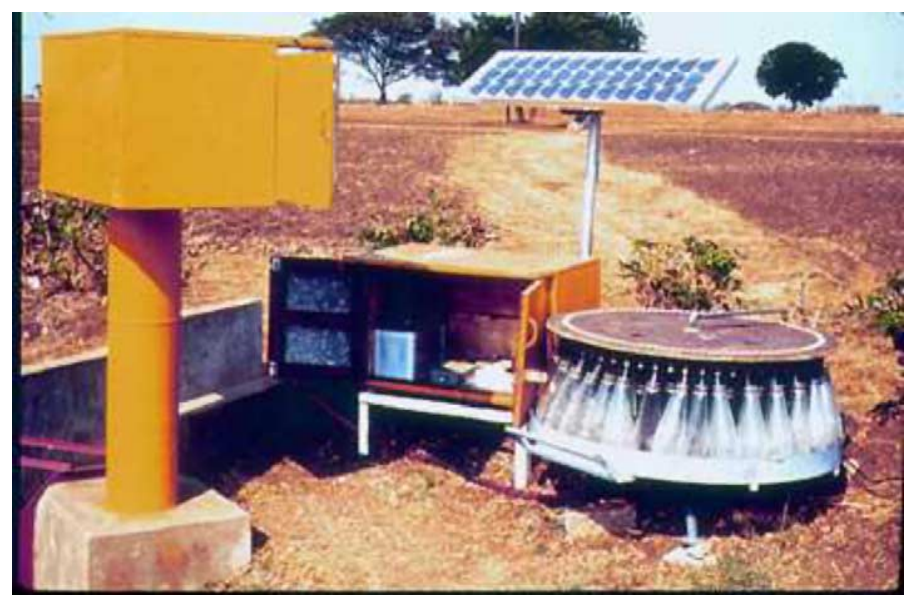

Fig. 3. Solar powered automatic pumping type runoff sampler.

concentration values were used to construct sediment concentration vs. time graph. This sediment concentration vs. time graph and the runoff hydrograph were then divided into small segments. For each segment the soil loss was calculated by multiplying the segment runoff volume $\times$ sediment concentration. The total soil loss during a runoff event was calculated by adding these segment values.

\section{Results and discussion}

Extreme variation in sediment concentration was observed during various runoff events. Fig. 4 shows sediment concentration variation with time for two runoff events measured at BW7A watershed. It is observed from Fig. 4 that the sediment concentration varied considerably with time and amount of flow during both runoff events. The figure also illustrates that on a watershed, the basic trend of sediment concentration with time can be quite different particularly during the early and rising part of the hydrographs. However, the trend of sediment concentration variation is quite similar during the recession component of both the hydrographs.

In order to ascertain how the sediment concentration varies with time on a watershed during various sized storms, the sediment concentration from 57 runoff events that occurred during 1976-2000 on BW1 watershed were plotted against time (Fig. 5). The time scale in Fig. 5 was calculated as a multiple of time to peak runoff rate, $\left(T_{\mathrm{p}}\right)$. This serves two purposes: firstly, it provides comparison of the sediment concentration variations between the storms in relation to their $T_{\mathrm{p}}$. Secondly, it provides an uniform scale for comparing various storms having extreme variations in runoff durations. On BW1 watershed, the variation in sediment concentration among the various storms can be seen from Fig. 5. During the early part of runoff, the variation in sediment concentration among various storms was extremely high. However, the variation in sediment concentration gradually decreased with an increase in time. One of the main reasons for the extreme variation in sediment concentration between 

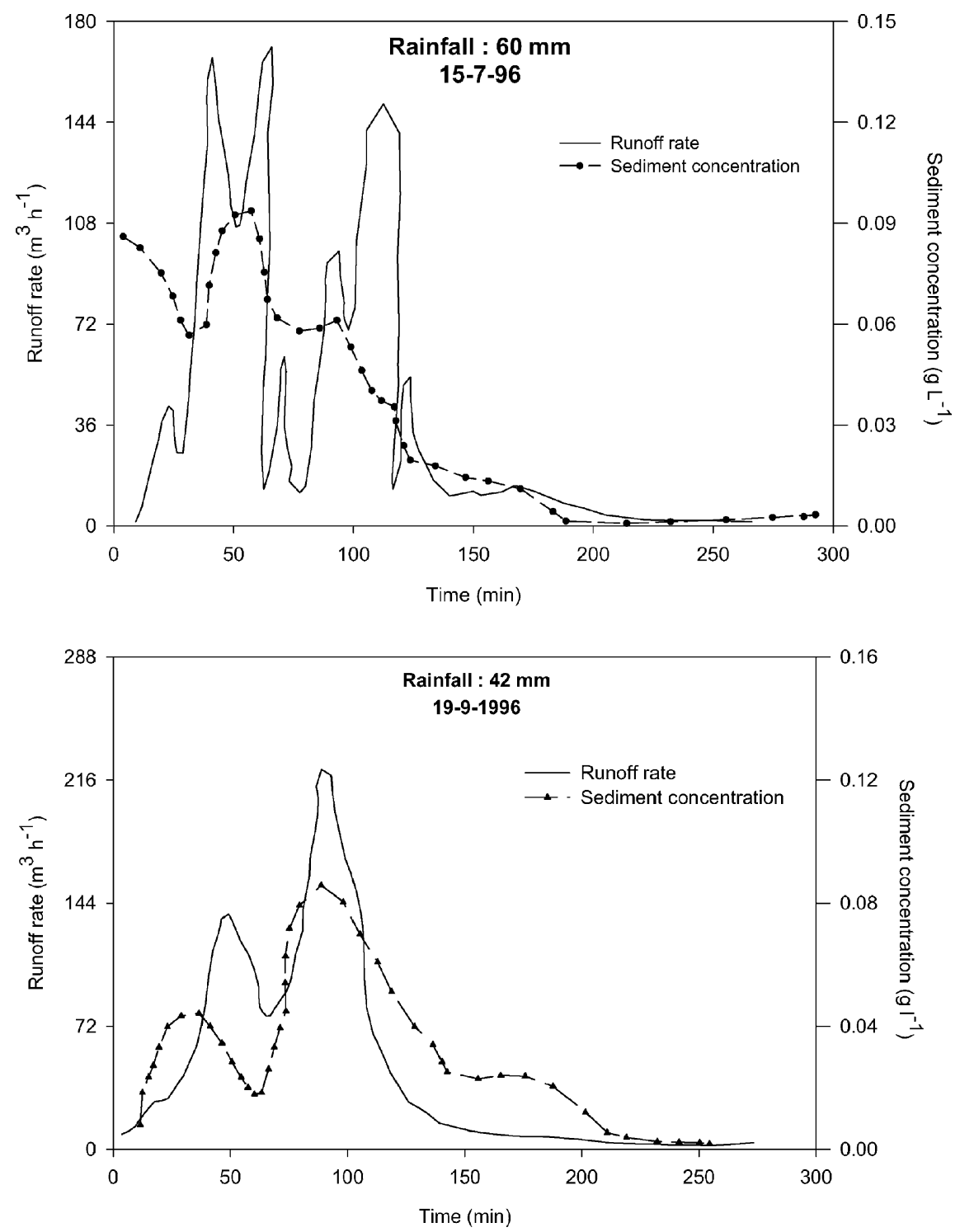

Fig. 4. Sediment concentration variation with time during two runoff events at BW7 watershed, 1996.

various storms during the early part of the runoff events is due to the differences in top soil conditions at which the various storms have occurred. It was found that storm which occurred when the top soil was loose (due to recent tillage, or intercultivation) resulted in extremely high sediment concentrations particularly during the early part of runoff event. Similarly storms which occurred after a long dry period also resulted generally in very high sediment concentrations particularly during the initial period of runoff. The reason 


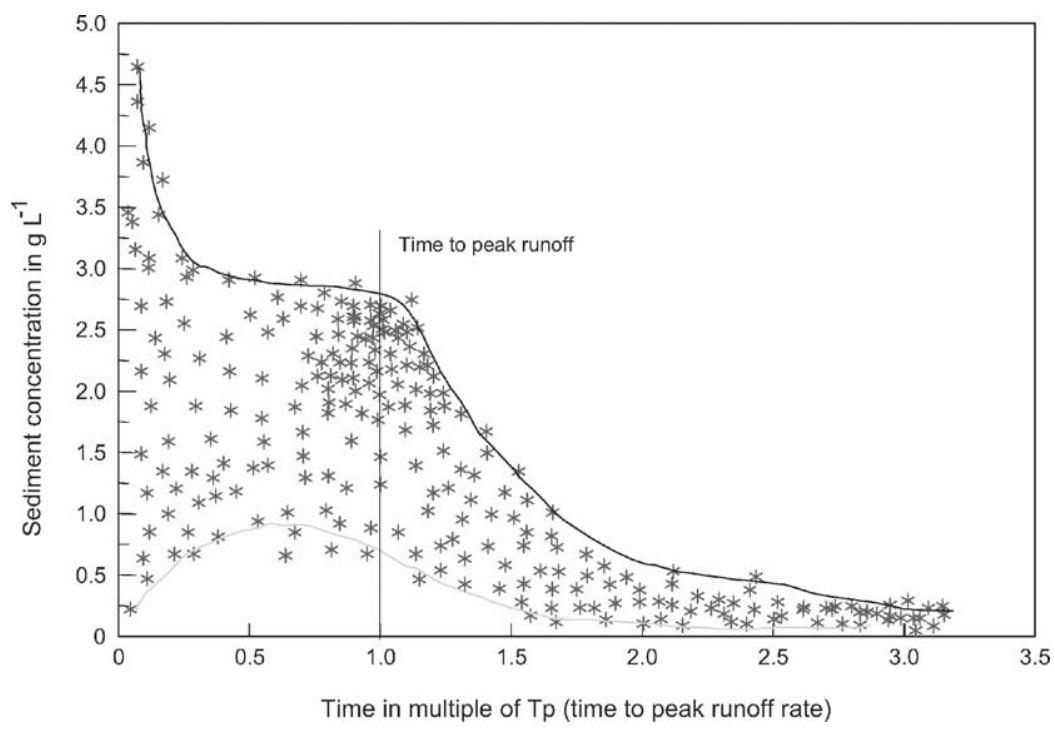

Fig. 5. Sediment concentration with time during various runoff events on a Vertisol watershed BW1.

for this phenomenon is that loose soil particles occur on the soil surface as a result of the self-mulching processes in Vertisols during prolonged dry periods. These loose particles are highly prone to erosion and are easily transported by the runoff resulting from subsequent storms. On the other hand, storms that followed heavy rain storms after the lapse of a short time interval resulted in very low sediment concentration particularly during the early part of runoff event. The main reason for this appears to be the fact that the preceding big storms have created sufficiently large size rills, channels etc., which were able to carry the low initial discharge of the storm without causing any serious erosion. As a result, the sediment in runoff resulting from storms preceded by big intense storms, is low. Another reason for the low sediment concentration could be the fact that the preceding big storm may have caused enough top soil compaction which may have resulted in low soil erosion by the subsequent storms. In spite of extreme variation in storm size and duration, the sediment concentration variation among storms was very low during the latter part of runoff event particularly after time $2.0 T_{\mathrm{p}}$ (Fig. 5).

Several other factors such as storm size, duration and intensity, changes in crop canopy during season, tillage timing, and changes in grass waterway conditions would explain major parts of sediment concentration variation among the various storms on a watershed (Fig. 5). The changes in rainfall intensity during the rainfall event could also provide explanations to some of the variation in sediment concentration observed during the runoff hydrograph.

Examination of the sediment concentration for individual storms indicates that for most of storms the peak sediment concentration generally preceded or occurred simultaneously with the peak runoff rates. Similar observations on the occurrence of peak sediment concentration have been reported by Hamlett et al. (1984); and Hamlett et al. (1987). However, 


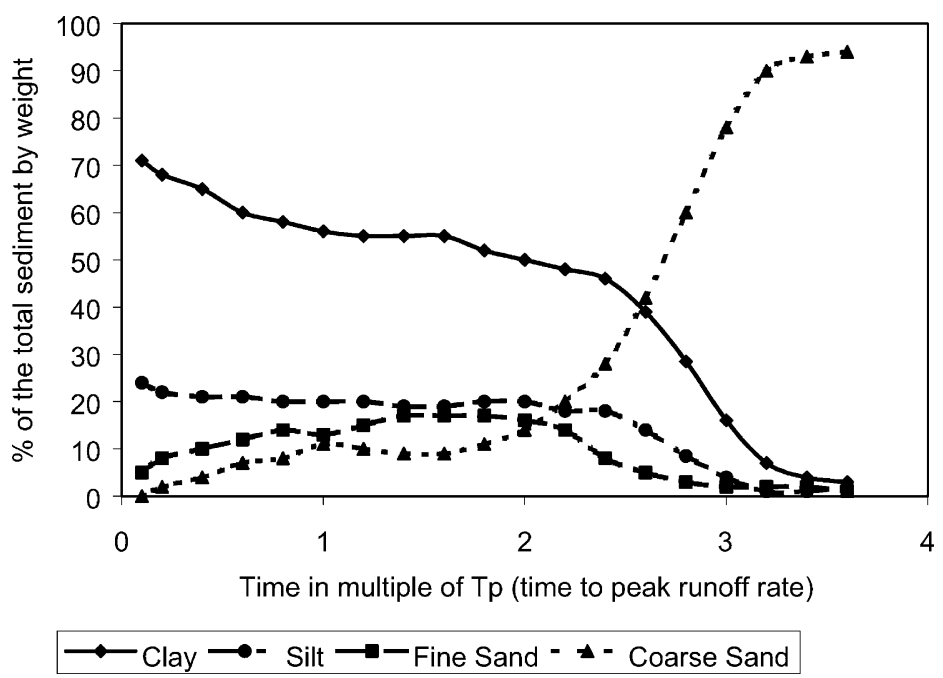

Fig. 6. Variation in size distribution of sediment during runoff events on BW1 watershed (weighted mean of 57 runoff events).

the peak sediment concentration for some runoff events occurred during the early part of runoff. Such storms usually occurred when the soil surface was very loose due to tillage or self-mulching process occurring in the soil during prolonged dry periods before the rains. The measurements from the other four watersheds, viz., BW2, BW3B, BW7A and BW7B showed similar trend of sediment concentration variation with time as shown in Fig. 5 for BW1 watershed. The difference in the sediment concentration among the five watersheds was only in the magnitudes of sediment concentration.

Considerable variation in the texture of eroded sediments during a runoff event can be seen from Fig. 6. The particle size distribution shown are the weighted mean values of 57 runoff events from BW1 watershed. The weighted mean particle size was determined separately for each hydrograph segment. For any hydrograph segment of a storm, the weightage was related to its contribution to the total soil loss during that hydrograph segment from all the 57 runoff events. The percentage of clay-size particles in the runoff was high at the beginning of a runoff event, and decreased as the runoff duration increased (Fig. 6). This is consistent with the observations of Doty and Carter (1965); Mitchell et al. (1983). The decrease in the clay content during runoff was more prominent during the early (from time $0-0.8 T_{\mathrm{p}}$ ) and the later part of runoff (from time 2.3-3.6 $T_{\mathrm{p}}$ ). Between time 0.8 and $2.3 T_{\mathrm{p}}$ the decline in clay content was small.

The silt content of the eroded sediment varied only slightly for a major part of the runoff event until after time 2.2 $T_{\mathrm{p}}$ after which there was a sharp decline. The coarse sand content in the runoff was low at the beginning of the event, but increased as the runoff duration increased. The initially low fine sand content of the runoff event increased gradually upto time $1.6 T_{\mathrm{p}}$ but decreased afterwards.

Comparison of the texture of the eroded sediments with that of cultivated soil layer in the watershed has provided some interesting information. At the beginning of the runoff 
Table 3

Effect of land management system on quantity and size distribution of eroded sediment

\begin{tabular}{|c|c|c|c|c|c|}
\hline \multirow[t]{2}{*}{ Land treatments } & \multirow{2}{*}{$\begin{array}{l}\text { Total soil sediments } \\
\left(\mathrm{kg} \mathrm{ha}^{-1}\right)\end{array}$} & \multicolumn{4}{|c|}{ Texture of eroded sediment $(\%)^{\mathrm{a}}$} \\
\hline & & Clay & Silt & Fine sand & Coarse sand \\
\hline $\mathrm{BBF}$ at $0.6 \%$ (BW1 watershed) & 15240 & 56 & 21 & 13 & 10 \\
\hline $\begin{array}{l}\text { BBF at } 0.6 \% \text { with field bunds } \\
\text { (BW2 watershed) }\end{array}$ & 7350 & 71 & 22 & 6 & 2 \\
\hline $\begin{array}{l}\text { Flat cultivation with field } \\
\text { bunds (BW3B watershed) }\end{array}$ & 21740 & 64 & 22 & 8 & 6 \\
\hline $\begin{array}{l}\text { Flat cultivation with graded } \\
\text { bunds (BW7A watershed) }\end{array}$ & 3270 & 57 & 21 & 11 & 11 \\
\hline $\begin{array}{c}\text { BBF at } 0.6 \% \text { with vegetative } \\
\text { bunds (BW7B watershed) }\end{array}$ & 2320 & 49 & 21 & 11 & 19 \\
\hline
\end{tabular}

a The average texture of the cultivated soil layer $(0-15 \mathrm{~cm})$ in the BW1, BW2 and BW3B watersheds is $53 \%$ clay, $20 \%$ silt, $14 \%$ fine sand, and $13 \%$ coarse sand, while in the BW7A and BW7B watersheds is $48 \%$ clay, $19 \%$ silt, $13 \%$ fine sand, and $20 \%$ coarse sand.

${ }^{\mathrm{b}}$ BW7A and BW7B data it is only for 1995-2000.

event, the eroded soils usually contained more clay fraction than the original soil. At the time to peak runoff rate however, particle size distribution of the eroded soil was quite similar to the original soil of the watershed. During the latter stages of runoff event, the eroded soil contained more coarse sand fraction than the original soil of the watershed.

Land management has shown considerable effect on the quantity as well as texture of eroded sediments (Table 3). The lowest clay content in the eroded soil was recorded from BW7B with broadbed and furrow system. In this treatment, the texture of the eroded soil was close to texture of the cultivated layer of watershed. Although the BW2 watershed had the lowest soil loss, the eroded soil contained the highest proportion of clay. Also, the eroded materials from BW2 watershed had very low content of coarse and fine sand. This may be due to the fact that BW2 watershed had a number of field bunds which created several small ponded areas in the watershed. These ponded zones have undoubtedly enhanced the deposition of sand particles, while the clay fraction remained in suspension and was therefore carried by runoff. The eroded soil from BW1 and BW7B which were under BBF had relatively high, fine and coarse sand content. It appears that with BBF which have large numbers of well graded furrows, the transporation of even heavier eroded soil particles is relatively easy. Compared to BBF land management system (BW7B), the flat system (BW7A) not only had more total soil loss but also its eroded soil contained relatively more clay.

The effect of storm size runoff on the size distribution of sediments from BW1 watershed is shown in Table 4. In general as the storm runoff size decreased, the percentage of finer soil particles, (viz. clay) in the eroded sediment increased. The texture of eroded soil from all the big runoff events (runoff $>40 \mathrm{~mm}$ ) were close to the texture of the cultivated soil layer of the watershed. On average the small runoff events had the highest percentage of clay and lowest percentage of coarse sand in their eroded material. This indicates that the low volume of runoff may not have high enough force to transport coarse soil particles. The 
Table 4

Storm wise variation in texture of eroded soil sediment from BW1 watershed (some selected storms 1976-2000)

\begin{tabular}{|c|c|c|c|c|c|c|}
\hline \multirow[t]{2}{*}{ Rainfall (mm) } & \multirow[t]{2}{*}{ Runoff (mm) } & \multirow[t]{2}{*}{ Soil loss $\left(\mathrm{kg} \mathrm{ha}^{-1}\right)$} & \multicolumn{4}{|c|}{ Texture of eroded sediment $(\%)$} \\
\hline & & & Clay & Silt & Fine sand & Coarse sand \\
\hline \multicolumn{7}{|c|}{ Big runoff events (runoff $* 40 \mathrm{~mm}$ ) } \\
\hline 150 & 94 & 1126 & 55 & 20 & 13 & 12 \\
\hline 128 & 46 & 557 & 52 & 20 & 13 & 15 \\
\hline 71 & 41 & 502 & 54 & 19 & 12 & 15 \\
\hline 64 & 47 & 419 & 55 & 22 & 13 & 10 \\
\hline 123 & 65 & 615 & 56 & 21 & 14 & 9 \\
\hline 65 & 43 & 585 & 54 & 23 & 12 & 11 \\
\hline Weighted me & & & 54 & 21 & 13 & 12 \\
\hline \multicolumn{7}{|c|}{ Medium runoff events (runoff $<40 * 15 \mathrm{~mm}$ ) } \\
\hline 35 & 25 & 134 & 55 & 20 & 13 & 12 \\
\hline 16 & 15 & 124 & 59 & 23 & 12 & 6 \\
\hline 49 & 23 & 210 & 58 & 22 & 13 & 7 \\
\hline 67 & 32 & 405 & 57 & 22 & 12 & 9 \\
\hline 82 & 36 & 705 & 58 & 18 & 13 & 11 \\
\hline 56 & 18 & 110 & 63 & 21 & 10 & 6 \\
\hline 43 & 23 & 175 & 62 & 20 & 11 & 7 \\
\hline Weighted me & & & 58 & 20 & 13 & 9 \\
\hline \multicolumn{7}{|c|}{ Small runoff events (runoff $<15 \mathrm{~mm}$ ) } \\
\hline 32 & 6 & 59 & 71 & 22 & 6 & 1 \\
\hline 31 & 11 & 100 & 63 & 22 & 10 & 5 \\
\hline 22 & 3 & 84 & 71 & 23 & 5 & 1 \\
\hline 36 & 7 & 210 & 69 & 21 & 7 & 3 \\
\hline 42 & 4 & 82 & 74 & 19 & 5 & 2 \\
\hline 20 & 2 & 25 & 70 & 20 & 6 & 4 \\
\hline 25 & 6 & 47 & 66 & 19 & 10 & 5 \\
\hline Weighted me & & & 69 & 21 & 7 & 3 \\
\hline
\end{tabular}

The texture of the cultivated soil layer of watershed BW 1 is: clay $53 \%$, silt $20 \%$, fine sand $14 \%$ and coarse sand $13 \%$.

major effect of size of runoff event was observed on percentage of clay and coarse sand in the eroded soil. The percentage of silt in the eroded soil was not influenced by size of runoff events.

The effect of storm size and land management systems on the texture of the eroded soil is shown in Fig. 7. Both the land management system and size of runoff events have considerable effect on the total soil loss and texture of the eroded material. For all the runoff events and land management systems, the values of dispersion coefficient (fraction of $<50$ micro meter in eroded material divided by the fraction of $<50$ micro meter of cultivated top soil) were greater than one indicating that the quantity of clay plus silt fraction in the eroded soil was greater than the clay plus silt fraction in the cultivated soil layer. For small and medium sized runoff events the differences between the land management systems for dispersion coefficient were quite significant. However, for big runoff events the difference between land management systems reduced considerably. 

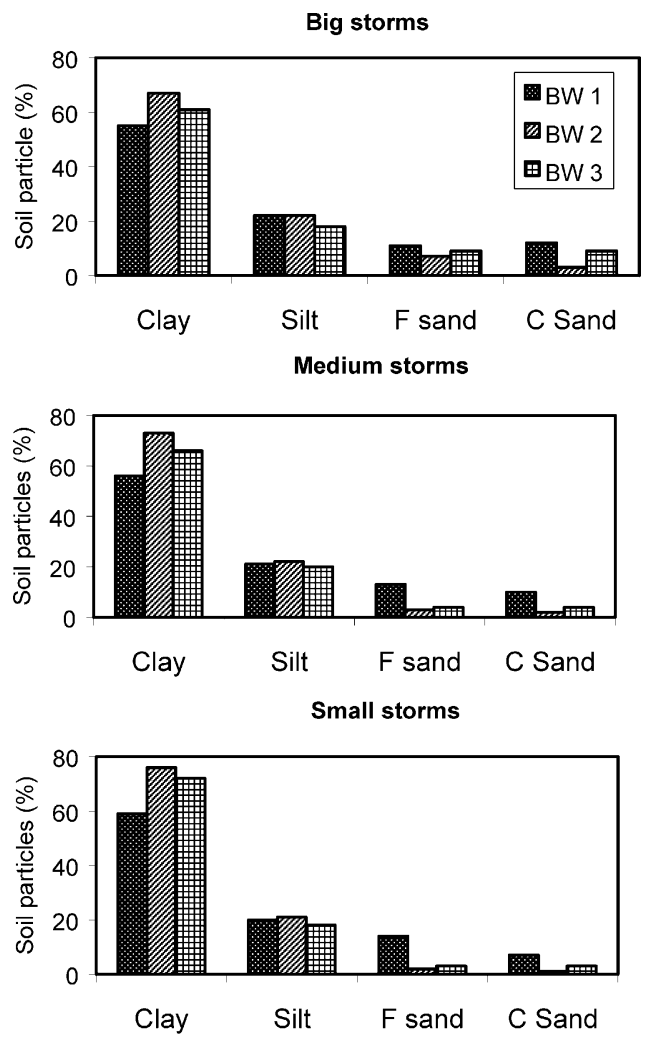

Fig. 7. Effect of storm size and land management systems on size of eroded soil particles.

\section{Summary and conclusion}

The following conclusions can be drawn from this study.

1. In majority of runoff events their peak sediment concentration generally preceded or occurred simultaneously with their peak runoff rates. The few runoff events which occurred when top soil was loose due to tillage or self-mulching of the soil, their peak sediment concentration generally occurred during early parts of runoff.

2. For a given site, the variation in sediment concentration between various storms was particularly high during the early part of runoff events. This variation in sediment concentration gradually decreased with increase in runoff time. The sediment concentration during the rising part of the runoff hydrograph usually did not follow any specific trend. However, the trend of sediment concentration variation during the recession part of hydrographs was quite similar for most of the runoff events.

3. At the initial stages of runoff events, the clay content of the eroded material was greater than that of the cultivated soil layer. As runoff duration increased, clay content of sediment tended to decrease. A totally reverse trend to that of clay in the sediment occurred 
for the fine and coarse sand fractions of the sediments. The content of silt in the sediment did not change much during most part of runoff event.

4. The texture of the eroded material was similar to the cultivated top soil within the watershed $(0-15 \mathrm{~cm}$ depth) at the time of peak runoff during many of the runoff events.

5. For a given site, as the storm runoff size decreased the content of clay and silt in the eroded material usually increased. The texture of eroded material from big runoff events (>40 mm) was usually similar to that of the cultivated soil layer of the watershed.

6. Land management systems have a significant effect on the total soil loss and its particle size distribution in the eroded sediments. The eroded sediments from flat cultivation contained more clay and silt than the BBF system.

\section{References}

Alberts, E.E., Moldenhauer, W.C., Foster, G.R., 1980. Soil aggregates and primary particles transported in rill and interrill flow. Soil Sci. Soc. Am. J. 44, 590-595.

Alberts, E.E., Wendt, R.C., Plest, R.F., 1983. Physical and chemical properties of eroded soil aggregates. Trans. ASAE 26 (2), 465-471.

Chichester, F.W., Richardson, C.W., 1992. Sediment and nutrient loss from clay soils as affected by tillage. J. Environ. Qual. 21 (4), 587-590.

Doty, C.W., Carter, C.E., 1965. Rates and particle size distribution of soil erosion from unit source areas. Trans. ASAE 8 (1), 309-311.

El-Swaify, S.A., Pathak, P., Rego, T.J., Singh, S., 1985. Soil management for optimized productivity under rainfed conditions in the semi-arid tropics. Adv. Soil Sci. 1 (1), 1-64.

Foster, G.R., Lane, L.J., Nowlin, J.D., Laflen, J.M., Young, R.A., 1980. A model to estimate sediment from field-sized areas. In: Walter, G.K. (Ed.), CREAMS. A field scale model for chemicals, runoff and erosion from agricultural management systems, vol. 1. USDA Rep. No. 26, pp. 36-64.

Gilley, J.E., Finkner, S.C., Spomer, R.G., Mielke, L.N., 1985. Size distribution of particles transported in rill and interrill flow. ASAE Paper 85-2536, ASAE St. Joseph, MI 49085, USA.

Gilley, J.E., Finkner, S.C., Varel, G.E., 1987. Size distribution of sediment as affected by surface residue and slope length. Trans. ASAE 30 (5), 1419-1424.

Hamlett, J.M., Kimes, S.C., Baker, J.L., Johnson, H.P., 1984. Runoff and sediment transport within and from a small agricultural watershed. Trans. ASAE 27, 1355-1363, and 1369.

Hamlett, J.M., Baker, J.L., Johnson, H.P., 1987. Size distribution of sediment transported within and from small agricultural watersheds. Trans. ASAE 30 (4), 998-1004.

Meyer, L.D., Harmon, W.C., McDowell, L.L., 1980. Sediment sizes eroded from crop row sideslopes. Trans. ASAE 23 (4), 891-898.

Meyer, L.D., Willoughby, W.E., Whisler, F.D., Rhoton, F.E., 1981. Predicting the size distribution of sediment from aggregated soils. ASAE Paper 81-2045, ASAE St. Joseph, MI 49085, USA.

Mitchell, J.K., Saled, M., Melcy, C.P., 1983. Primary particle and aggregate size distribution of eroded soil from sequenced rainfall events. Trans. ASAE 26 (6), 1773-1777.

Niebling, W.H., Foster, G.R., Holbert, P.V., 1983. Deposition of naturally eroded sediment on concave slope. ASAE Paper 83-2160, ASAE St. Joseph, MI 49085, USA.

Onstad, C.A., Young, R.A., Otterby, M.A., Holt, R.F., 1979. Sediment yield modeling for 208 planning. In: Peterson, A.E., Swan, J.B. (Eds.), Universal Soil Loss Equation-Past, Present and Future. Soil Sci. Soc. Am. Madison, WI, USA, pp. 25-32.

Overton, D.E., 1992. Soil erosion and sediment yield: modeling, simulation and prediction. Stormwater Publications, Knoxville, TN, USA, 197 pp.

Pathak, P., 1991. Runoff sampler for small agricultural watersheds. Agric. Water Manage. 19, 105-115.

Pathak, P., 1999. Runoff and soil loss measurement. In: Wani, S.P., Singh, P., Pathak, P. (Eds.), Methods and Management of Data for Watershed Research, ICRISAT Center, Patancheru, India. Technical manual no. 5, International Crops Research Institute for the Semi-Arid Tropics, Patancheru, AP, India, pp. 15-40. 
Pathak, P., Miranda, S.M., 1982. Sediment flow and its measurement from small agricultural watersheds. In: Proceedings of the XIX Annual Convention of Indian Society of Agricultural Engineers. College of Technology and Agricultural Engineering, University of Udaipur, Rajasthan, 15-17 February 1982.

Pathak, P., Miranda, S.M., El-Swaify, S.A., 1985. Improved rainfed farming for semi-arid tropics-implications for soil and water conservation. In: El-Swaify, S.A., Moldenhauer, W.C., Andrew, L. (Eds.), Soil Erosion and Conservation. Soil Conservation Society of America, Iowa, USA, pp. 338-354.

Pathak, P., Laryea, K.B., 1990. Prospects of water harvesting and its utilization for agriculture in the semi-arid tropics. In: Proceeding of the Symposium of the SADCC Land and Water Management Research Program Scientific Conference. Gaborone, Botswana, 8-10 October, 1990, pp. 266-278.

Pathak, P., Sudi, R., Wani, S.P., Srinivasa Rao, C., 2002. Runoff harvesting and utilization for agriculture in the semi-arid watersheds. In: Proceedings of the Symposium of All India Seminar on Advances in Agricultural Mechanization. The Institution of Engineers, Bangalore, India, 27-28 December 2002, pp. 207-217.

Sutherland, R.A., 1991. Selective erosion and sediment source identification, Baringo District, Kenya. (En) Zeitschrfit fur Geomorphologie 35 (3), 293-304.

Young, R., 1980. Characteristics of eroded sediment. Trans. ASAE 23 (5), 1139-1146. 